\title{
Eoarchean Iron Metabolism?
}

\author{
TUE HASSENKAM*1, ESTHER H. R. TSAI ${ }^{2}$, HENNING O. \\ SøRENSEN $^{1}$, KIM N. DALBY ${ }^{1}$, DAVID M. A. \\ MACKENZIE $^{3}$, MIRKO HOLLER ${ }^{2}$, DARIO FERREIRA ${ }^{2}$, \\ DANIEL GROLIMUND ${ }^{2}$, STEFAN BRUNS ${ }^{1}$, MinIK T. \\ ROSING $^{1}$
}

\footnotetext{
${ }^{1}$ Globe insitute, University of Copenhagen, 1350, Denmark

${ }^{2}$ Paul Scherrer Institut, 5232 Villigen PSI,Switzerland

${ }^{3}$ Center for Nanostructured Graphene (CNG), Department of Micro- and Nanotechnology, Technical University of Denmark, Kongens Lyngby, 2800, Denmark

*Correspondence to: tue.hassenkam@sund.ku.dk
}

Metasedimentary rocks from Isua, West Greenland ( $>3,7$ Ga old) contain carbonaceous compounds, compatible with a biogenic origin[1,2]. The metamorphic mineral assemblage with garnet and quartz intergrowths contains layers of carbonaceous inclusions contiguous with carbon-rich sedimentary beds in the host rock. Here we report on evidence which could provide new insights into the nature of the life that generated this carbonaceous material. We studied material trapped in inclusions armoured within quartz grains inside garnet porphyroblasts by non-destructive ptychographic X-ray nanotomography (PXCT). The 3D electron density maps generated by PXCT were correlated with maps from X-ray fluorescence tomography and microRaman spectroscopy. We found that the material trapped inside inclusions in the quartz grains consist of nano-graphitic material encasing domains of iron-rich carbonaceous material. These results corroborates earlier claims[1,2] for biogenic origins and are compatible with relics of metamorphosed biological material originally containing high iron /carbon ratios, similar to organisms using iron in their metabolic functions. Therefore, we present the potentially oldest direct evidence in Earths geological record for life relying on iron metabolism.

\section{References:}

[1] Hassenkam et al (2017), Nature 548, 78-81

[2] Rosing (1999), Sience 283, 674-676 